As-Syifaa Jurnal Farmasi Juli 2019; 11 (01): 38-44.

ISSN : 2085-4714

\title{
ANALISIS KADAR KUERSETIN PADA EKSTRAK ETANOL DAUN MIANA (Plectranthus scutellarioides (L.) R.Br.) SECARA HPLC (High Performance Liquid Chromatography)
}

\author{
Sukmawati, Harti Widiastuti, Miftahuljanna
}

Fakultas Farmasi, Universitas Muslim Indonesia, Makassar

Email: sukmawati.syarif@umi.ac.id

\begin{abstract}
One of the medicinal plants that people often use as a medicine is the Miana leaves (Plectranthus scutellarioides (L.) R.Br.). The Miana leaves are empirically used to treat coughs, heart disease, worm medicines, antimicrobials, antioxidants, antiseptics, bronchitis, hemorrhoids, tuberculosis, and other pharmacological activities. The miana leaves contain secondary metabolite compounds of flavonoids, steroids, tannins, and saponins. One of the most critical flavonoids is quercetin. This study aimed to determine the quercetin content of ethanol extract of miana leaves by HPLC (High Performance Liquid Cromatography). The extraction method by maceration using 96\% ethanol. Determination of quercetin content in miana leaf ethanol extract by HPLC with $C_{18}$ column, maximum wavelength of $369.11 \mathrm{~nm}$ with mobile phase methanol : aquabides (59:41) flow rate of 1 $\mathrm{mL} /$ minute. The results showed retention time for quercetin as a comparison of 4,183 minutes, a sample of 4.563 minutes, and an additional sample of 4,363 minutes. The average content of quercetin in miana leaf ethanol extract was $3.122 \mathrm{mg} / \mathrm{g}$ or 0,312\%.
\end{abstract}

Key Words : Miana leaves, quercetin, HPLC.

\section{PENDAHULUAN}

Sejak lama tumbuhan dikenal oleh masyarakat memiliki khasiat sebagai obat. Obat tradisional telah dikenal dan digunakan secara turun-temurun oleh masyarakat Indonesia. Pemanfaatan obat tradisional pada umumnya lebih diutamakan untuk menjaga kesehatan, meskipun pemanfaatanya ada pula ditujukan sebagai pengobatan suatu penyakit. ${ }^{1}$

Salah satu tanaman obat yang sering digunakan masyarakat sebagai obat ialah daun miana (Plectranthus scutellarioides (L.) R.Br.). Masyarakat Indonesia menggunakan tanaman ini untuk mengobati batuk, sebagai terapi penyakit jantung, penambah nafsumakan menetralisir racun, menghilangkan gumpalan darah, obat cacing, antimikroba, antioksidan, antiseptik, bronkitis, wasir, TBC, dan aktivitas farmakologi lainnya. ${ }^{2}$ Corak, bentuk, dan warna miana beranekaragam, tetapi yang berkhasiat obat adalah daun yang berwarna merah kecoklatan. ${ }^{3}$

Daun miana mengandung senyawa metabolit sekunder flavonoid, steroid, tanin dan Saponin. ${ }^{4}$ Hal ini didukung pula penelitian sebelumnya yang menemukan bahwa hasil penapisan fitokimia daun miana memiliki metabolit sekunder berupa flavonoid, steroid, tanin, dan saponin. ${ }^{5}$ Pada daun miana (Plectranthus scutellarioides (L.) R.Br.) banyak mengandung flavonoid, dimana salah satu flavonoid yang paling penting adalah kuersetin. ${ }^{6}$ Pada penelitian sebelumnya menyatakan bahwa daun miana mengandung kuersetin. $^{7}$

Kuersetin merupakan golongan flavonoid dilaporkan menunjukkan beberapa aktivitas biologi. Aktivitas ini dikaitkan dengan sifat antioksidan kuersetin, antara lain karena 
Analisis kadar kuersetin pada ekstrak etanol daun miana (Plectranthus scutellarioides (L.) R.Br.) secara HPLC

kemampuan menangkap radikal bebas dan spesi oksigen reaktif seperti anion superoksida dan radikal hidroksil. $^{8} \quad$ Kuersetin dapat berfungsi sebagai antioksidan, antikanker, antialergi, antivirus, diabetes, hipertensi dan antiinflamasi. ${ }^{9}$ Hasil dari studi yang dilakukan peneliti sebelumnya menunjukkan bahwa senyawa-senyawa flavonoid alami seperti kaempferol, morin, myricetin, dan kuercetin memiliki aktivitas perlindungan yang bervariasi terhadap penurunan kandungan $\alpha$-tokoferol dalam LDL. ${ }^{10}$

Berdasarkan uraian di atas, mengenai aktifitas farmakologi senyawa kuersetin yang begitu potensial maka perlu dilakukan analisis kadar kuersetin yang terkandung pada daun miana (Plectranthus scutellarioides (L.)R.Br.) dengan menggunakan metode HPLC (High Performance Liquid Chromatography), agar penelitian ini mampu memberikan data ilmiah tentang pemanfaatan daun miana (Plectranthus scutellarioides (L.)R.Br.) sebagai bahan obat herbal.

\section{METODE PENELITIAN}

Pembuatan ekstrak etanol daun miana (Plectranthus scutellarioides (L.) R.Br.).

\begin{tabular}{ccr} 
Daun & miana & \multicolumn{2}{c}{ (Plectranthus } \\
scutellarioides & (L.)R.Br.) & yang telah
\end{tabular}
diserbukkan sebanyak 100 gram dimasukkan ke dalam bejana maserasi, lalu ditambahkan cairan penyari etanol 96\% sebanyak $1500 \mathrm{~mL}$ hingga simplisia tersebut terendam, dibiarkan selama 3 hari dalam bejana tertutup dan terlindungi dari cahaya matahari langsung dan diaduk pada waktu pagi, siang, dan sore selama $3 \times 24$ jam dilakukan penyaringan untuk mendapatkan ekstrak etanol cair, kemudian residu dari proses maserasi diremaserasi dengan menggunakan cairan penyari etanol $96 \%$ sebanyak $1300 \mathrm{~mL}$, kemudian diaduk dan diamkan selama 3 hari. Ekstrak etanol cair yang diperoleh dicampur dengan hasil penyaringan remaserasi pertama. Residu dari remaserasi pertama dilarutkan kembali dengan cairan penyari etanol $96 \%$ yang baru sebanyak $1200 \mathrm{~mL}$, kemudian di aduk dan diamkan selama 3 hari. Hasil penyaringan yang diperoleh digabung dan kemudian diuapkan dengan menggunakan rotary vakum evaporator sehingga akan diperoleh ekstrak etanol kental. ${ }^{11}$

Penetapan kadar kuersetin ekstrak etanol daun miana (Plectranthus scutellarioides (L.) R.Br.) secara HPLC (High Performance Liquid Chromatography).

Penentuan panjang gelombang maksimum kuersetin dilakukan dengan merunning larutan kuersetin konsentrasi 3 ppm menggunakan spektorfotometer UV-Vis pada range panjang gelombang $300-700 \mathrm{~nm}$ sehingga diperoleh panjang gelombang maksimal 369,11 nm. Analisis kualitatif dilakukan dengan membandingkan retention time yang sama (identik) dari kromatogram larutan sampel dengan kromatogram larutan baku pembanding kuersetin pada kondisi HPLC yang sama. ${ }^{12}$ Standar kuersetin ditimbang $10 \mathrm{mg}$, kemudian dilarutkan dengan $10 \mathrm{~mL}$ metanol (Larutan induk 1000 ppm). Lalu dipipet sebanyak $0,25 \mathrm{~mL}$ dilarutkan dalam labu takar $5 \mathrm{~mL}$ dengan pelarut metanol hingga batas tanda (Kadar kuersetin menjadi 50 ppm). Larutan baku pembanding 50 ppm dipipet sebanyak $0,6,0,8,1$, dan $1,2 \mathrm{~mL}$, masing-masing dimasukkan ke dalam labu ukur $5 \mathrm{~mL}$, lalu diencerkan dengan pelarut sampai garis tanda, sehingga diperoleh konsentrasi masing-masing larutan adalah 6,8,10 dan 12 ppm. Masing-masing larutan 
Analisis kadar kuersetin pada ekstrak etanol daun miana (Plectranthus scutellarioides (L.) R.Br.) secara HPLC

disaring melalui membran filter $0,45 \mu \mathrm{m}$ dan disonikator selama 20 menit. Setelah itu diinjeksikan masing-masing larutan ke dalam sistem HPLC sebanyak $60 \mu \mathrm{L}$ pada kondisi suhu ruang dengan fase gerak, metanol : aquabides (59: 41), laju alir $1 \mathrm{~mL} /$ menit. Kromatogram direkam dan dibuat kurva kalibrasi antara luas area puncak dengan konsentrasi. ${ }^{8}$ Sampel ekstrak etanol daun miana (Plectranthus scutellarioides (L)R.Br.) ditimbang $10 \mathrm{mg}$, kemudian dilarutkan dengan $10 \mathrm{~mL}$ metanol dengan demikian diperoleh konsentrasi 1000 ppm kemudian di tambahkan $1 \mathrm{~mL}$ larutan baku 50 ppm, setelah itu, larutan sampel disaring melalui membrane filter 0,45 $\mu \mathrm{m}$ dan disonikator selama 20 menit. Setelah itu injeksikan ke dalam sistem HPLC sebanyak $60 \mu \mathrm{L}$ pada kondisi suhu ruang dengan fase gerak, metanol : aquabides (59:41), laju alir 1 $\mathrm{mL} /$ menit, panjang gelombang $\lambda \max 369,11$ $\mathrm{nm}$ dan kromatogram direkam. ${ }^{8}$

Dari hasil pengukuran, area yang diperoleh dicatat, lalu dihitung kadarnya menggunakan kurva kalibrasi (persamaan regresi linear) : $\mathbf{y}=\mathbf{a}+\mathbf{b x}$

\section{HASIL DAN PEMBAHASAN}

Penelitian ini bertujuan untuk mengetahui dan menentukan kadar kuersetin ekstrak etanol daun miana (Plectranthus scutellarioides (L.)R.Br.) secara HPLC (High Performance Liquid Chromatography), dimana untuk menarik senyawa kuersetin yang terkandung dalam sampel daun miana dilakukan proses ekstraksi pada sampel daun miana (Plectranthus scutellarioides (L.)R.Br.) tersebut. Simplisia daun miana (Plectranthus scutellarioides (L.)R.Br.) diekstraksi dengan cara dingim yaitu metode maserasi menggunakan pelarut etanol 96\%. Alasan menggunakan etanol $96 \%$ sebagai pelarut yaitu karena memiliki sifat kelarutan yang sama dengan senyawa yang ingin ditarik yaitu kuersetin. Dilihat dari strukturnya senyawa kuersetin yang ada dalam daun miana (Plectranthus scutellarioides (L.)R.Br.) merupakan senyawa polifenol yang bersifat polar sehingga harus dilarutkan dengan pelarut polar. ${ }^{13}$

Metode maserasi ini sangat menguntungkan karena selain murah dan mudah dilakukan, juga tidak merusak senyawa yang tidak tahan pemanasan. Hal ini disesuaikan pada sifat fisika dan kimia dari golongan senyawa yang terkandung dalam daun miana (Plectranthus scutellarioides (L.)R.Br.) yaitu golongan senyawa flavonoid. Senyawa flavonoid adalah golongan senyawa yang tidak tahan panas dan mudah teroksidasi pada suhu tinggi. ${ }^{14}$ dimana kuersetin adalah senyawa kelompok flavonoid golongan flavonol.

Hasil maserasi selanjutnya diuapkan dengan rotary vacum evaporator sampai diperoleh ekstrak kental. Ekstrak kental yang diperoleh yaitu 14,554 gram. Hasil rendamen ekstrak kental daun miana Plectranthus scutellarioides (L.)R.Br.) yaitu 14,554 \% dapat dilihat pada tabel 1. Alasan dihitung persen rendamen adalah agar dapat mengetahui kadar metabolit sekunder yang terbawa oleh pelarut namun tidak dapat menentukan jenis senyawa yang terbawa. ${ }^{15}$

$\begin{array}{rrr} & \text { Analisis kuersetin dalam ekstrak } \\ \text { etanol daun miana (Plectranthus }\end{array}$
scutellarioides (L.)R.Br.) secara HPLC (High Performance Liquid Chromatography) diawali dengan penentuan panjang gelombang maksimum. Panjang gelombang maksimum adalah panjang gelombang ketika terjadi serapan cahaya maksimum 
Analisis kadar kuersetin pada ekstrak etanol daun miana (Plectranthus scutellarioides (L.) R.Br.) secara HPLC

oleh senyawa yang dianalisis. ${ }^{16}$ Didapatkan panjang gelombang maksimum yaitu pada panjang gelombang $369.11 \mathrm{~nm}$ yang sebelumnya dilakukan running menggunakan spektorfotometer UV-Vis pada range panjang gelombang pada $300-700 \mathrm{~nm}$.

Tabel 1. Hasil perhitungan persenrendemen ekstrak etanol daun miana (Plectranthus scutellarioides (L.)R.Br.).

\begin{tabular}{ccccc}
\hline Sampel & $\begin{array}{c}\text { Bobot simplisia } \\
(\mathbf{g})\end{array}$ & $\begin{array}{c}\text { Hasil ekstraksi } \\
\mathbf{( g )}\end{array}$ & $\begin{array}{c}\text { Jumlah pelarut } \\
\text { metanol }(\mathbf{m L})\end{array}$ & $\begin{array}{c}\text { Rendemen } \\
\text { ekstrak (\%) }\end{array}$ \\
\hline Daun Miana & 100 & 14,554 & 4000 & 14,554 \\
\hline
\end{tabular}

Berdasarkan hasil analisis kualitatif yang dilakukan terhadap sampel ekstrak etanol daun miana (Plectranthus scutellarioides (L.)R.Br.), sampel tersebut positif mengandung senyawa kuersetin, dimana dapat dilihat dari retention time (RT) antara larutan baku dan larutan sampel sama. Pada larutan baku kuersetin konsentrasi 50 ppm dengan nilai luas area puncak sebesar 4068130 pada retention time (RT) yaitu 4,183 dan pada larutan sampel konsentrasi 1000 ppm dengan nilai luas area puncak sebesar 293962 pada retention time (RT) yaitu 4,563. Namun, karna kadar kuersetin dalam sampel konsentrasinya sangat sedikit sehingga peak yang muncul juga sangat rendah, maka dari itu digunakan metode adisi, dimana metode adisi adalah suatu penambahan larutan standar ke dalam larutan sampel dengan tujuan untuk memastikan senyawa yang terdapat pada sampel, yang di tandai dengan meningkatnya peak setelah pengukuran kembali pada sampel 1000 ppm yang telah di tambahkan $1 \mathrm{~mL}$ larutan standar konsentrasi $50 \mathrm{ppm}$. Hasil pengukuran metode adisi yaitu nilai luas area puncak sebesar 918249 pada retention time (RT) yaitu 4,363. Hal ini mendakan bahwa pada sampel ekstrak etanol daun miana (Plectranthus scutellarioides (L.)R.Br.) terdapat senyawa kuersetin. Hasil pengukuran analisis kualitatif dapat dilihat pada tabel 2 berikut ini :

Tabel 2. Hasil pengukuran analisis kualitatif

\begin{tabular}{ccc}
\hline Uji retention time & Area & Retention time (Menit) \\
\hline Baku kuersetin 50 ppm & 4068130 & 4,183 \\
Sampel 1000 ppm & 293962 & 4,563 \\
1000 ppm S + 50 ppm A & 918249 & 4,363
\end{tabular}

Keterangan: $\mathrm{S}$ = Sampel; $\mathrm{A}=$ Adisi

Analisis kuantitatif diawali dengan pembuatan larutan baku standar kuersetin dengan modifikasi dari 50 ppm yang kemudian dibuat 4 seri konsentrasi (ppm) masingmasing larutan adalah 6, 8, 10 dan 12 ppm, pada rangkaian larutan standar tersebut masing-masing dicukupkan volumenya hingga $5 \mathrm{~mL}$ dengan metanol, lalu disaring dengan membran fltrat $0,45 \mu \mathrm{m}$ selanjutnya masingmasing disonikasi untuk menghilangkan gelembung atau udara. Kemudian diinjeksikan pada alat HPLC (High Performance Liquid 
Analisis kadar kuersetin pada ekstrak etanol daun miana (Plectranthus scutellarioides (L.) R.Br.) secara HPLC

Chromatography) dengan volume injeksi 60 $\mu \mathrm{m}$ dengan laju alir $1 \mathrm{~mL} /$ menit dengan panjang gelombang $\lambda \max \quad 369.11 \mathrm{~nm}$. Kromatogram direkam dan dibuat kurva kalibrasi antara luas area puncak dengan konsentrasi. Hasil pengukuran baku standar kuersetin dapat dilihat pada tabel 3. Dari data

Tabel 3. Hasil pengukuran baku kuersetin tersebut dibuat persamaan regresi linier dengan menghubungkan antara konsentrasi dan luas area puncak kromatogram, data tersebut dapat dilihat pada gambar 1. Dari kurva kalibrasi diperoleh persamaan garis $y=$ $76919 x-27386$, nilai $r=0,994$, dan nilai $V x_{0}=$ $0,000504 \%$

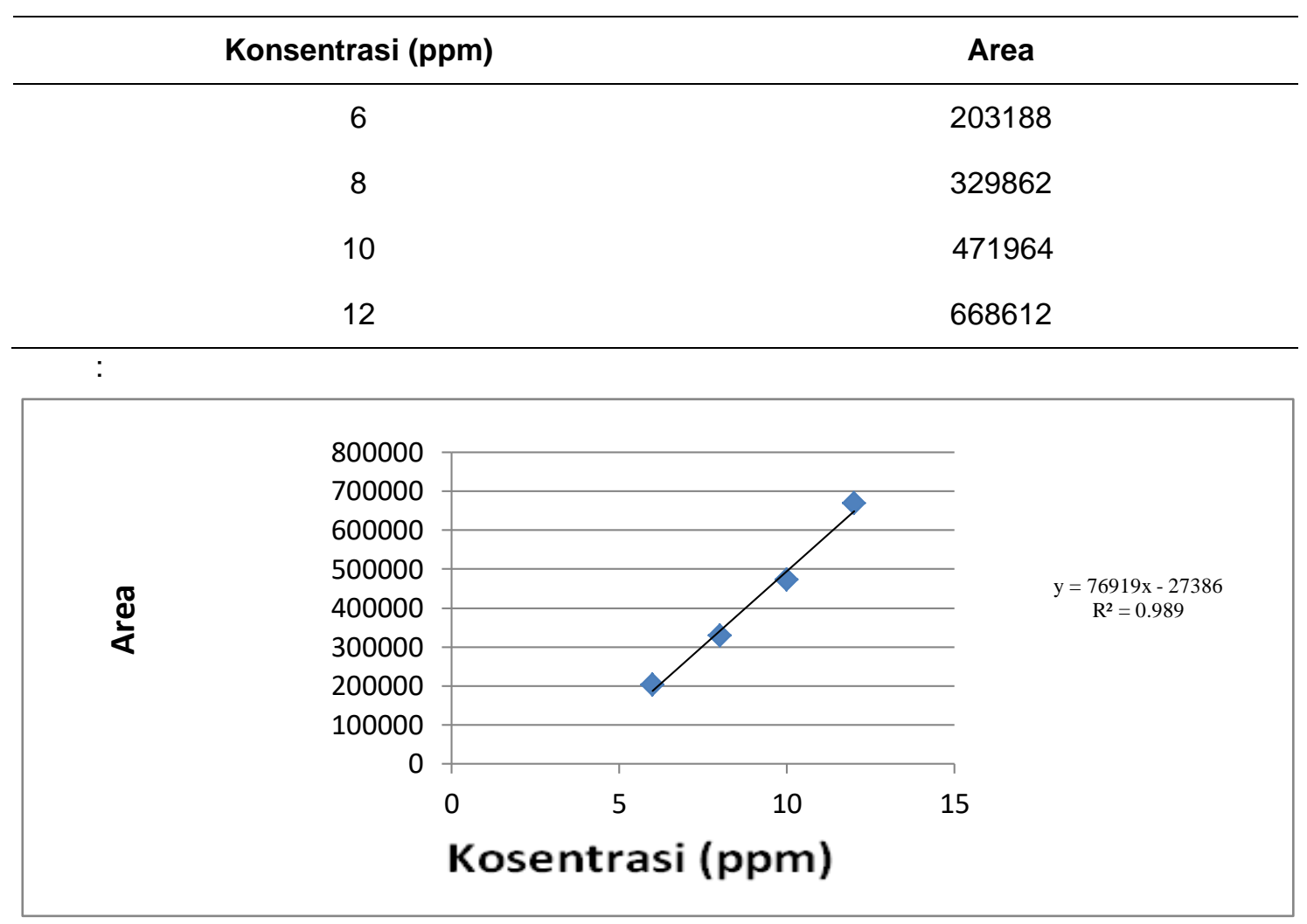

\section{Gambar 1. Kurva baku Kuersetin}

Kurva baku merupakan kurva yang dibuat dari sederetan larutan baku yang masih dalam batas linieritas sehingga dapat diregresi linierkan. Fungsinya biasanya digunakan untuk menunjukkan besarnya konsentrasi larutan sampel dari hasil pengukuran sehingga konsentrasi sampel larutan dapat diperoleh dengan mudah melalui kurva baku. Kurva baku menunjukkan hubungan antara konsentrasi larutan (sumbu $\mathrm{x}$ ) dengan area (sumbu y) dari kurva baku akan dihasilkan suatu persamaan yang diregresikan yaitu persamaan $y=a+b x$ dimana $y=$ variable terikat, $\mathrm{x}=$ variable bebas, $\mathrm{a}=$ intersep dan $\mathrm{b}$ $=$ koefisien regresi $/$ slop.

Linearitas memiliki dua syarat yaitu syarat pertama nilai koefisien korelasi yang dikatakan baik apabila diperoleh nilai $r \geq 0,998$ dan koefisien fungsi regresi $(\mathrm{V} \times 0)$ dimana nilainya tidak boleh $<5 \%$. ${ }^{16}$ Hasil $\mathrm{Vx}_{0}$ dari pengukuran yaitu $0,000504 \%$ dan ini sesuai dengan persyaratan, sehingga kadar kuersetin pada sampel dapat ditetapkan dan dihitung.

Hasil luas area dari rangkaian konsentrasi larutan baku kuersetin diplotkan dengan konsentrasinya untuk memperoleh 
Analisis kadar kuersetin pada ekstrak etanol daun miana (Plectranthus scutellarioides (L.) R.Br.) secara HPLC

kurva baku kuersetin dengan persamaan garis

$y=76919 x-27386$ dengan nilai korelasi $(r)$

0,994 dan nilai $V x_{0}$ sebesar $0,000504 \%$.

Berdasarkan hasil analisis pada HPLC

yang dilakukan terhadap sampel daun miana ekstrak etanol daun miana (Plectranthus scutellarioides (L)R.Br.), dapat dilihat pada tabel 4 berikut ini :

Tabel 4. Hasil pengukuran sampel ekstrak etanol daun miana (Plectranthus scutellarioides (L.)R.Br.)

\begin{tabular}{ccccccc}
\hline Sampel & Replikasi & Berat ekstrak (g) & Area (y) & $\begin{array}{c}\text { Kadar kuersetin } \\
(\mathbf{m g} / \mathbf{g})\end{array}$ & $\begin{array}{c}\text { Rata-rata kadar } \\
\text { kuersetin }(\mathbf{m g} / \mathbf{g})\end{array}$ & $\begin{array}{c}\text { Rata-rata kadar } \\
\text { kuersetin }(\%)\end{array}$ \\
\hline $\begin{array}{c}\text { Ekstrak } \\
\text { etanol daun } \\
\text { miana }\end{array}$ & 1 & 0,01005 & 588890 & 3,449 & & 3,122 \\
\hline
\end{tabular}

Hasil analisis kuantitatif diperoleh kadar kuersetin pada sampel R1 yaitu 3,449 $\mathrm{mg} / \mathrm{g}$ sedangkan kadar kuersetin pada sampel replikasi R2 yaitu 2,796 $\mathrm{mg} / \mathrm{g}$ dan hasil akhir analisis kuantitatif pada sampel ekstrak etanol daun miana (Plectranthus scutellarioides (L.)R.Br.) mengandung kadar rata- rata kuersetin yaitu $3,122 \mathrm{mg} / \mathrm{g}$ dan kadar kuersetin dalam persen sebesar $0,312 \%$.

\section{KESIMPULAN}

Berdasarkan hasil penelitian yang telah dilakukan maka dapat disimpulkan bahwa ekstrak etanol daun miana (Plectranthus scutellarioides (L.)R.Br.) memiliki kandungan kuersetin. Ekstrak etanol daun miana (Plectranthus scutellarioides (L.)R.Br.) mengandung kadar rata- rata kuersetin yaitu $3,122 \mathrm{mg} / \mathrm{g}$ dan kadar kuersetin dalam persen sebesar $0,312 \%$.

\section{DAFTAR PUSTAKA}

1. Suharmiati, Maryani H. Daun Dewa dan Sambung Nyawa. Jakarta: Agromedia Pustaka, 2003:24.

2. Ahmad A, Massi MN. The antituberculosis drug rifampicin is activated by 2', 5'dimethyl benzopelargonolactone from the leaf of Coleus atropurpureus L. Benth. International journal of Pharma and Bio Science 2014;5(1):758-764.

3. Lisdiwati V, Mutiatikum D, Alegantina S, Astuti Y. Karakteristik daun miana
(Plectranthus scuttellarioides (L) Bth.) dan buah sirih (Piper betle L.) secara fisiko kimia dari ramuan lokal antimalaria Daerah Sulawesi Utara. Media Litbang Kesehatan Badan Libagkes 2008;18(4):213-225.

4. Dalimartha S. Atlas Tumbuhan Obat Indonesia Jilid 2. Jakarta: Trubus Agriwidya, 2006.

5. Ridwan Y, Ayunina JQ. Fitokimia dan aktivitas biologi anticestoda beberapa varietes miana (Coleus blumei Benth). J Prof. 2007;14:23-28.

6. Ridwan $Y$, Darusman KL, Satrija $F$, Handayani E. Kandungan kimia berbagai ekstrak daun miana (Coleus blumei Benth.) dan efek anthelmintiknya terhadap cacing pita pada ayam. J II Pert Indon 2006;11(2):1-6.

7. Lumbessy M, Abidjulu J, Paedonga JJE. Uji Total Flavonoid pada beberapa Tanaman Obat Tradisional Di Desa Waitina Kecamtan Mangoli Timur Kabupaten Kepulauan Sula Provinsi Maluku Utara. Jur MIPA Unstrat Online 2013;2(1):50-55.

8. Moektiwardoyo M, Levita J, Sidiq PS, Ahmad K, Mustarichie R, Subarnas A, Supriyatna. The Determination of Quercetin in Plectranthus scutellarioides (L.) R.Br. Leaves Extract and its in Silico Study on Histamine H4 Receptor. Bandung: Faculty of Pharmacy Universitas Padjadjaran. 2011;22(3):91-192.

9. Nugraha A, Ghozali MT. Penetapan kadar flavonoid kuersetin ekstrak kulit buah apel hijau (Pyrus malus L.) dengan 
Analisis kadar kuersetin pada ekstrak etanol daun miana (Plectranthus scutellarioides (L.) R.Br.) secara HPLC

menggunakan metode kromatografi cair kinerja tinggi. 2017.2-3.

10. Kelly SG. Monograph Quercetin. Alternative Medicine Review 2011; 16(2):172.

11. Zhu, Qin Yan, Yu Huang, Zhen-Yu Chen. Interactions Between Flavonoids and $\alpha$ Tocopherol in Human Low Density Lipoprotein. Jurnal Nutr Biochem 2000;11:14-21.

12. Rahmi A, Cahyono $T$, Sujarwo $T$, Lestari RI. Uji Aktivitas Antibakteri Estrak daun beluntas (Pluches indica (L.)Less) Terhadap Propionibacteterium acnes penyebab jerawat. Jurnal Fakultas Sains dari Teknologi UIN Sunan Gunung 2015;9(1):141-161.

13. Dewi, PS. Penetapan kadar Akrilamida dalam Kentang Goreng pada Restoran Cepat Saji di Kota Medan secara KCKT (Skripsi). Medan: Fakultas Farmasi USU, 2010.
14. Syofyan, Lucida $H$, Bakhtiar A. Peningkatan Kelarutan Kuersetin Melalui Pembentukan Kompeks Inklusi dengan (Siklodekstrin). Jurnal Sains dan Teknologi Farmasi 2008;13(2):43-48.

15. Rompas RA, Edy HJ, Yudistira A. Isolasi dan identifikasi flavonoid dalam daun lamun (Syringodium isoetifolium).Pharmacon 2012;1(2):59-63.

16. Ukieyanna E. Aktivitas antioksidan, kadar fenolik, dan flavonoid total tumbuhan suruhan (Peperomia pellucid L Kunth). (Skripsi). Bogor: Fakultas Teknologi Pertanian, Institut Pertanian Bogor, 2012:7.

17. Harmita. Petunjuk pelaksaanan validasi metode dan cara perhitungannya. Departemen Farmasi FMIPAUI.2004;1(3):129. 